\title{
SOLID-STATE FERMENTATION OF BREWER'S SPENT GRAIN FOR XYLANOLYTIC ENZYMES PRODUCTION BY Penicillium janczewskii AND ANALYSES OF THE FERMENTED SUBSTRATE
}

\author{
FERMENTAÇÃO EM ESTADO SÓLIDO COM BAGAÇO DE CEVADA PARA \\ PRODUÇÃO DE ENZIMAS XILANOLÍTICAS POR Penicillium janczewskii E \\ ANÁLISE DO SUBSTRATO FERMENTADO
}

\author{
César Rafael Fanchini TERRASAN ${ }^{\mathbf{1}}$; Eleonora Cano CARMONA ${ }^{\mathbf{1}}$ \\ 1. Biochemistry and Microbiology Department, Biosciences Institute, Univ. Estadual Paulista - UNESP, Rio Claro, SP, Brazil. \\ ecarmona@rc.unesp.br
}

\begin{abstract}
In recent decades, increasing interest has been devoted to xylanolytic enzymes due to their potential use in many industrial processes. This study describes the production of xylanase, $\beta$-xylosidase and $\alpha$-Larabinofuranosidase, belonging to the xylanolytic complex, by Penicillium janczewskii using brewer's spent grain as substrate for solid-state fermentation. The optimized conditions for high levels of xylanase, $\beta$-xylosidase and $\alpha$-Larabinofuranosidase production were: $50 \%$ initial moisture, which was provided by Vogel's salt solution, seven days of cultivation at $20-30{ }^{\circ} \mathrm{C}$. Fermentation enriched the bioproduct with some amino acids and did not add mycotoxins to it. The use of brewer's spent grain as substrate for fungal cultivation and enzyme production can both add value to this waste and reduce the production cost of xylanolytic enzymes.
\end{abstract}

KEYWORDS: Enzyme production. Xylanolytic enzymes. Penicillium janczewskii. Solid-state fermentation. Brewer's spent grain.

\section{INTRODUCTION}

Xylan is the most common hemicellulose and it is composed mainly of D-xylose, although other sugars may be present as substituents of the principal chain. Due to its complex structure, the complete breakdown of xylan requires several enzymes acting cooperatively, known as xylanolytic system. Endo- $\beta-1,4$-xylanase $\quad(4-\beta$-D-xylan xylanohydrolase EC 3.2.1.8) is the main enzyme responsible for xylan depolymerization, breaking the main chain, releasing xylooligosaccharides, while $\beta$-xylosidase (4- $\beta$-D-xylan xylohydrolase, EC 3.2.1.37) removes xylose from non-reducing ends of xylobiose and other xylooligosaccharides. Other enzymes responsible for removing xylan substituents such as $\alpha$-L-arabinofuranosidase (EC 3.2.1.55), $\alpha$-glucuronidase, and acetyl xylan, feruloyl, and p-coumaroyl esterases have been referred as auxiliary or accessory xylanolytic enzymes. These enzymes are important for the complete enzymatic hydrolysis of the xylan since side chains can restrict enzyme action on the polymer main chain (BIELY, 1985; BIELY, 2003; BEG et al., 2001).

Complete xylanolytic systems have been found to be quite widespread among fungi, actinomycetes, and bacteria; and the production of xylanolytic enzymes by Penicillium species has been often related (POLIZELI et al., 2005; CHÁVEZ et al., 2006). Filamentous fungi usually secrete plant cell wall degrading enzymes into the medium, releasing energy and nutrients from plant biopolymers. This physiological characteristic is interesting from the industrial point of view because it eliminates the need for releasing the enzymes by cell disruption in the downstream process; moreover the levels of extracellular enzymes produced by fungi are higher than those from yeasts and bacteria (KNOB et al., 2010).

In many countries, agricultural or agro industrial wastes constitute a problem, mainly those generated in large quantities and those that do not receive proper disposal. Therefore, such residues can be considered excellent substrates for the growth of filamentous fungi especially by solid-state fermentation that allows the use of these wastes, available in large amounts and usually at low cost, turning the production process economically profitable. On the other hand, it solves the problem of waste disposal that would cause, otherwise, environmental pollution (SOCCOL; VANDENBERGH, 2003; SINGHANIA et al., 2009). Moreover, when used for animal feed, the fermented substrate is more easily digested due to the presence of the enzymes and also presents higher nutritional value, especially in relation to the protein content (GRAMINHA et al., 2008).

Brewer's spent grain (BSG) is the main byproduct of the brewing industry, and it is primarily composed of $28 \%$ arabinoxylan, $28 \%$ lignin and $17 \%$ cellulose. Despite of the large 
Solid-state fermentation...

amounts generated annually, BSG has received little attention and its use on large scale is limited to animal feed (MUSSATTO; ROBERTO, 2006; MUSSATTO et al., 2006; ALIYU; BALA, 2011). Some studies have investigated BSG as substrate for xylanolytic enzymes production by different microorganisms (NASCIMENTO et al., 2002; PANAGIOTOU et al., 2006; 2007; MANDALARI et al., 2008; TERRASAN et al., 2010). However, there are no studies evaluating specifically the use of BSG for animal feed, after biological or enzymatic treatment. In this regard, there is only one publication about the effect of BSG supplemented with exogenous xylanases in the development of broilers (DENSTALDI et al., 2010). Thus, the conversion of renewable agricultural sources to bioproducts with improved nutritional quality to be used for feed supplementation can be considered a challenging area in biotechnology.

In this sense, the use of solid-state fermentation (SSF) as an alternative to decrease the costs of enzyme production, and also the possibility of subsequent use of the fermented substrate for animal feed turn this technique quite economical and environmentally advantageous. The objective of this work was to optimize the culture parameters one-variable-at-a-time for the production of xylanase, $\beta$-xylosidase and $\alpha$-L-arabinofuranosidase by $P$. janczewskii in solid cultures with BSG and evaluate the properties of fermented material for animal feed.

\section{MATERIAL AND METHODS}

\section{Microorganism: maintenance and inoculum production}

Penicillium janczewskii strain (CRM 1348) is deposited in The Central of Microbial Resources, CMR-UNESP, Brazil. The microorganism was maintained in Vogel solid medium (VOGEL, 1956) with $1.5 \%(\mathrm{w} / \mathrm{v})$ wheat bran at $4{ }^{\circ} \mathrm{C}$ and cultured periodically. Cultures were inoculated in the same medium with $1.5 \%$ (w/v) glucose and incubated for 7 days at $28{ }^{\circ} \mathrm{C}$ for conidia production. Conidia were harvested and suspended in distilled water, tap water or Vogel's salt solution (as described below), and the concentration was adjusted to $10^{7}$ conidia $\mathrm{mL}^{-1}$.

\section{Cultivation on BSG for enzyme production}

Solid-state fermentation was performed in triplicate in $250 \mathrm{~mL}$ Erlenmeyer flasks containing 5 $\mathrm{g}$ of dried BSG. BSG was provided by a local brewery (Baungartner, Ipeúna, São Paulo, Brazil)
TERRASAN, C. R. F.; CARMONA, E. C.

and exhaustively washed with distilled water and dried at $80{ }^{\circ} \mathrm{C}$ to constant weight.

Initial 20, 30, 40 and 50\% (v/w) moistures were established with distilled water, tap water or Vogel's salt solution (VOGEL, 1956). Each medium was then inoculated with $1 \mathrm{~mL}$ of the conidia suspension completing the moisture content, according to the cultivation parameters. Cultivation was carried out for 7 days at $28^{\circ} \mathrm{C}$.

Production of xylanase, $\beta$-xylosidase and $\alpha$ L-arabinofuranosidase was followed for 15 days at $28^{\circ} \mathrm{C}$ starting with $50 \%(\mathrm{v} / \mathrm{w})$ moisture in medium established with Vogel's salt solution.

Production of xylanase, $\beta$-xylosidase and $\alpha$ L-arabinofuranosidase was evaluated after 7 days incubation under different temperatures from 20 to $35{ }^{\circ} \mathrm{C}$, starting with $50 \%(\mathrm{v} / \mathrm{w})$ moisture in medium established with Vogel's salt solution.

\section{Preparation of the crude extract}

Extraction of the enzymes was performed by adding $50 \mathrm{~mL}$ of ice-cold distilled water to the fermentation medium followed by orbital shaking (200 rpm, $30 \mathrm{~min}$.) under refrigeration. The resulting suspension was vacuum filtered and the filtrate was used as source of extracellular proteins.

\section{Determination of protein and enzyme activities}

The protein concentration was determined by the modified Bradford method (SEDMACK; GROSSBERG, 1977) using bovine serum albumin as standard.

Xylanase activity was determined, according to Bailey et al. (1992) using 1.0\% (w/v) birchwood xylan (Sigma) in a $0.05 \mathrm{M}$ sodium acetate $\mathrm{pH} 5.5$ buffered reaction and appropriately diluted enzyme solution at $50{ }^{\circ} \mathrm{C}$; the reducing sugars were quantified with dinitrosalicylic acid reagent (MILLER, 1959). $\beta$-xylosidase and $\alpha$-Larabinofuranosidase activities were determined using $\quad 0.25 \% \quad(w / v) \quad \rho$-nitrophenyl $\beta$-Dxylopyranoside (Sigma) and $\rho$-nitrophenyl $\alpha$-Larabinofuranoside (Sigma), respectively, in McIlvaine $\mathrm{pH} 4.0$ buffered reaction and appropriately diluted enzyme solution, at $50{ }^{\circ} \mathrm{C}$. The reaction was stopped with a saturated sodium tetraborate solution, and the absorbance was read at $405 \mathrm{~nm}$ (KERSTERS-HILDERSON et al., 1982). One unit of enzyme activity was defined as the amount of enzyme required to release $1 \mu \mathrm{mol}$ of product equivalent (reducing ends for xylanase assays or $\rho$-nitrophenol for $\beta$-xylosidase and $\alpha$-Larabinofuranosidase assays) per min in the assay conditions. Specific activities were expressed as enzyme units per milligram of protein. 


\section{Chemical analysis}

Samples of the fermented BSG were predried and used for determination of dry matter, mineral matter, crude protein and ether extract according to AOAC (1990), and neutral detergent fiber (NDF) and acid detergent fiber (ADF), according to Van Soest (1994). Hemicellulose was calculated as the difference between NDF and ADF, and cellulose as the difference between ADF and ADL (acid detergent lignin). Analyses were performed by Biobell Technologies, Mirassol, SP, Brazil. Non-fermented BSG sample was prepared in the same conditions and used as control.

\section{Amino acid composition}

Amino acid determinations were carried out before and after acid hydrolysis. The crude material $(5 \mathrm{mg})$ was hydrolyzed with a solution of $6 \mathrm{~mol} \mathrm{l}^{-1}$ of $\mathrm{HCl}(1 \mathrm{~mL})$ and $5 \%$ phenol/water solution $(0.08$ $\mathrm{mL}$ ) for $72 \mathrm{~h}$ at $110{ }^{\circ} \mathrm{C}$ to guarantee quantitative hydrolysis of peptide bounds. Pyrex tubes with plastic Teflon-coated screw caps $(13.0 \times 1.0 \mathrm{~cm})$ were used for hydrolysis. Samples were dried, diluted with $1.0 \mathrm{~mL}$ of citrate buffer $\mathrm{pH} 2.2$ and filtered in a GV Millex Unity (Millipore). Amino acids analyses were performance by cation exchange chromatography using an automated amino acid analyzer Shimadzu LC-10A/C-47A, with sodium eluents and post-column derivatization with OPA (o-phthaldialdehyde) (FOUNTOULAKIS; LAHM, 1998). Amino acid identification and quantification was performed comparing each peak profile (retention time and area) with a standard amino acid mixture (17 amino

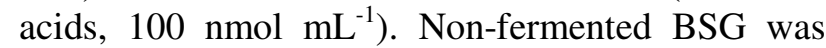
prepared in the same conditions and used as control.

\section{Mycotoxin analysis}

Analysis of mycotoxins was performed by Eurofins Food Analysis Ltd. Ochratoxin A was determined with an immunoaffinity column cleanup in HPLC with fluorescence detection, according to modified EN 14132 Method (ENTWISLE et al., 2001). Zearalenone and deoxynivalenol were extracted with acetonitrile:water (1:1, v:v), solidphase extraction (SPE) clean-up, solvent-exchange, and HPLC-MS/MS analysis, according to internal method. Patulin was extracted with ethylacetate, followed by partitioning of the extract with aqueous sodium carbonate solution, and analyzed by HPLC
TERRASAN, C. R. F.; CARMONA, E. C.

with DAD detector, according to internal method. Aflatoxins were extracted, transferred to phosphate buffered saline, cleaned up with monoclonal antibody affinity column. After elution, the aflatoxins were post-derivatized using a cobra-cellreactor and then analyzed by HPLC with fluorescence detection, according to internal method based on European Standard EN 14123. Nonfermented BSG was prepared in the same conditions and used as control.

\section{RESULTS AND DISCUSSION}

\section{Production of xylanolytic enzymes by $P$. janczewskii in solid-state fermentation of BSG}

The xylanase, $\beta$-xylosidase and $\alpha-\mathrm{L}-$ arabinofuranosidase production by $P$. janczewskii increased with the moisture content, with the highest enzyme production observed in $40 \%$ ( $\alpha$-Larabinofuranosidase) and $50 \%$ (xylanase and $\beta$ xylosidase) moisturized cultures. This effect can be assigned to the faster growth of the microorganism in the highly moisturized cultures, resulting in higher enzyme production (KALOGERIS et al., 1998). Strong reduction in enzyme yields was obtained at lower moisture contents (Table 1).

Many studies reported similar effects with intermediate or higher moisture contents favoring the production of xylanolytic enzymes by fungi as Aspergillus niger (MACIEL et al., 2008), Fusarium oxysporum (XIROS et al., 2008a), Melanocarpus albomyces (NARANG et al., 2001), Neurospora crassa (XIROS et al., 2008b), Paecilomyces themophila (YANG et al., 2006), Penicillium brasilianum (MAMMA et al., 2007) and Penicillium canescens (BAKRI et al., 2003). Furthermore, it is noteworthy that the xylanase and $\alpha$-Larabinofuranosidase productions were much higher when the moisture was provided by Vogel's salt solution than the production obtained in cultures moisturized with distilled or tap water. These results suggest that the presence of the different salts in this solution favor fungal growth, increasing enzyme production. However, for $\beta$-xylosidase production, similar activity yields were obtained using both Vogel's salt solution or distilled water. Higher values of specific activities were also observed in $50 \%$ moisturized cultures with distilled or tap water. 
Table 1. Xylanase, $\beta$-xylosidase and $\alpha$-L-arabinofuranosidase production by $P$. janczewskii in solid-state cultivation with brewer's spent grain at different initial moisture content.

\begin{tabular}{|c|c|c|c|c|c|c|c|}
\hline & \multirow{3}{*}{$\begin{array}{l}\text { Initial } \\
\text { moisture } \\
(\%)\end{array}$} & \multicolumn{6}{|c|}{ Enzyme activity } \\
\hline & & \multicolumn{2}{|c|}{ Xylanase } & \multicolumn{2}{|c|}{$\beta$-xylosidase } & \multicolumn{2}{|c|}{$\alpha$-L-arabinofuranosidase } \\
\hline & & (U/g dry BSG) & (U/mg prot.) & (mU/g dry BSG) & (mU/mg prot.) & (mU/g dry BSG) & (mU/mg prot.) \\
\hline \multirow{4}{*}{$\begin{array}{l}\text { Vogel's } \\
\text { salt } \\
\text { solution }\end{array}$} & 20 & $22.8 \pm 2.3$ & $38.6 \pm 2.1$ & $23.8 \pm 2.9$ & $37.5 \pm 8.4$ & $29.7 \pm 2.3$ & $50.9 \pm 8.9$ \\
\hline & 30 & $145.7 \pm 13.1$ & $102.8 \pm 11.2$ & $97.7 \pm 10.9$ & $70.7 \pm 8.9$ & $236.8 \pm 33.0$ & $165.4 \pm 32.9$ \\
\hline & 40 & $209.2 \pm 6.4$ & $134.4 \pm 4.0$ & $169.6 \pm 5.1$ & $108.9 \pm 2.8$ & $674.8 \pm 30.9$ & $229.0 \pm 32.8$ \\
\hline & 50 & $370.0 \pm 30.1$ & $159.3 \pm 8.9$ & $246.5 \pm 14.7$ & $106.2 \pm 8.9$ & $606.7 \pm 19.5$ & $291.3 \pm 19.5$ \\
\hline \multirow{4}{*}{$\begin{array}{l}\text { Distilled } \\
\text { water }\end{array}$} & 20 & $19.5 \pm 1.9$ & $2190.2 \pm 75.9$ & $21.5 \pm 2.0$ & $2586.4 \pm 125.8$ & $17.0 \pm 1.8$ & $2111.2 \pm 521.4$ \\
\hline & 30 & $80.8 \pm 2.1$ & $4474.3 \pm 318.6$ & $102.0 \pm 6.2$ & $5602.7 \pm 148.7$ & $91.6 \pm 4.3$ & $4919.3 \pm 454.2$ \\
\hline & 40 & $165.6 \pm 7.4$ & $5853.3 \pm 382.7$ & $188.2 \pm 6.2$ & $6642.2 \pm 237.5$ & $177.1 \pm 13.7$ & $6250.2 \pm 467.4$ \\
\hline & 50 & $263.9 \pm 7.0$ & $7889.2 \pm 407.1$ & $245.6 \pm 16.2$ & $7341.0 \pm 564.6$ & $227.6 \pm 15.1$ & $6793.6 \pm 297.2$ \\
\hline \multirow{4}{*}{$\begin{array}{c}\text { Tap } \\
\text { water }\end{array}$} & 20 & $12.8 \pm 0.4$ & $1858.3 \pm 112.9$ & $14.7 \pm 1.0$ & $2136.4 \pm 24.7$ & $12.7 \pm 1.0$ & $1841.9 \pm 164.7$ \\
\hline & 30 & $53.2 \pm 2.7$ & $3641.8 \pm 138.5$ & $54.6 \pm 2.2$ & $3736.9 \pm 79.9$ & $55.7 \pm 3.7$ & $3812.9 \pm 161.1$ \\
\hline & 40 & $136.7 \pm 10.4$ & $5419.3 \pm 337.0$ & $134.0 \pm 4.7$ & $5466.3 \pm 419.2$ & $155.3 \pm 13.7$ & $6379.9 \pm 365.0$ \\
\hline & 50 & $169.7 \pm 4.8$ & $4954.7 \pm 149.4$ & $181.2 \pm 16.1$ & $5283.0 \pm 489.2$ & $220.6 \pm 20.9$ & $6425.6 \pm 549.2$ \\
\hline
\end{tabular}

Cultivation was carried in $250 \mathrm{~mL}$ Erlenmeyer flasks containing $5 \mathrm{~g}$ of dried BSG for 7 days at $28{ }^{\circ} \mathrm{C}$. Data are mean and standard deviation of triplicates. 
Xylanase production increased until the seventh day of cultivation, when it reached the maximal yield (371 U/g dry BSG), and decreased at the eighth day, from which remained stable until the 11th day, decreasing slowly in the following days (Figure 1a).
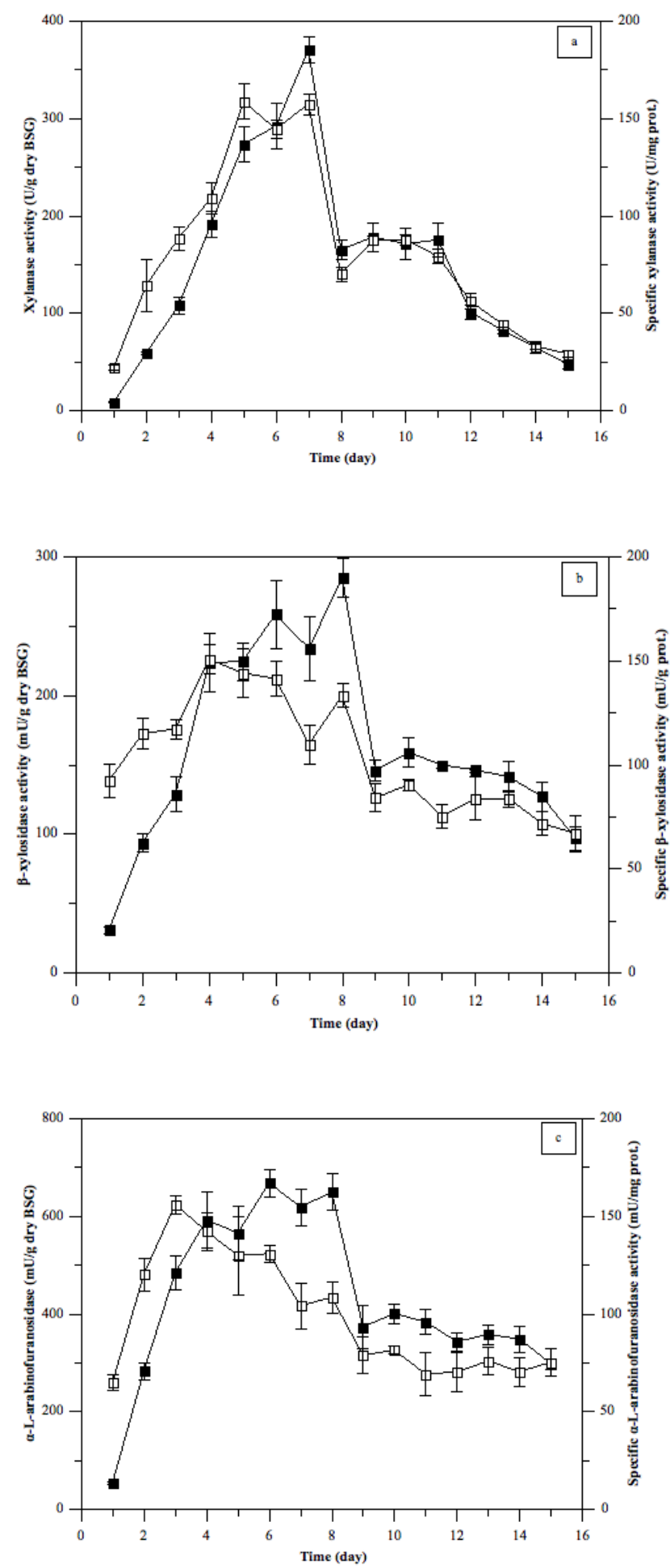

Figure 1. Time-course of xylanase (a), $\beta$-xylosidase (b) and $\alpha$-L-arabinofuranosidase (c) production by $P$. janczewskii in solid-state fermentation with brewer's spent grain. Growth conditions: $50 \%(\mathrm{v} / \mathrm{w})$ initial moisture established with Vogel's salt solution at $28{ }^{\circ} \mathrm{C}$. (घ) Enzyme activity (U/g BSG or $\mathrm{mU} / \mathrm{g} \mathrm{BSG}$ ); ( $\square$ ) Specific enzyme activity (U/mg prot. or $\mathrm{mU} / \mathrm{g}$ prot.). 
Solid-state fermentation...

The highest values of specific activity were observed from the fifth to seventh day $(\approx 150 \mathrm{U} / \mathrm{mg}$ prot.). Considering the experimental error, the $\beta$ xylosidase production increased until the eighth day ( $285 \mathrm{mU} / \mathrm{g} \mathrm{BSG})$, decaying from this. High values of specific activity were observed from the fourth to seventh day, corresponding to approximately 150 $\mathrm{mU} / \mathrm{mg}$ prot. (Figure 1b). The $\alpha-\mathrm{L}$ arabinofuranosidase production increased until the sixth day (668 mU/g dry BSG), remained stable up to the eighth day decreasing from this. The highest specific $\alpha$-L-arabinofuranosidase activity was observed at the third day of cultivation (Figure 1c).

Similar pattern of time-dependent enzyme production was reported for other fungal strains, e.g. Paecilomyces themophila after eight days of growth on solid medium with wheat bran (Yang et al., 2006); Penicillium brasilianum after 96, 108 and $196 \mathrm{~h}$ (4.0, 4.5 and 8.2 days) of growth on BSG produced the highest yields of xylanase, arabinofuranosidase and feruloyl esterase activities (Panagiotou et al., 2006; 2007); Fusarium
TERRASAN, C. R. F.; CARMONA, E. C.

oxysporum after $144 \mathrm{~h}$ (5 days) of growth in a reactor containing BSG and corncobs (FES) produced the highest yields of xylanolytic enzymes (Xiros et al., 2008a). These results are supported by the fact that $\beta$-xylosidases are only required after the initial action of xylanases on the substrate. The reduction of the enzyme activities may be associated to the production of proteases, a secondary and undesirable process that decreases the net productivity of the xylanolytic enzymes.

The production of xylanases, $\beta$-xylosidases and $\alpha$-L-arabinofuranosidases by $P$. janczewskii was evaluated in cultivations carried out at $20,25,30$ and $35{ }^{\circ} \mathrm{C}$. As presented in Table 2, the highest xylanase production was verified at $25{ }^{\circ} \mathrm{C}$, the highest the $\beta$-xylosidase production occurred at 20 ${ }^{\circ} \mathrm{C}$, and the highest $\alpha$-L-arabinofuranosidase production occurred at $30{ }^{\circ} \mathrm{C}$. Similarly, Panagiotou et al. $(2006 ; 2007)$ found the highest production of xylanase, arabinofuranosidase and feruloyl esterase by $P$. brasilianum at temperatures between 25 and $30{ }^{\circ} \mathrm{C}$.

Table 2. Xylanase, $\beta$-xylosidase, and $\alpha$-L-arabinofuranosidase production by $P$. janczewskii in solid-state cultivation with brewer's spent grain at different temperatures.

\begin{tabular}{ccccccc}
\hline \multirow{2}{*}{$\begin{array}{c}\text { Temperatur } \\
\text { e }\left({ }^{\circ} \mathrm{C}\right)\end{array}$} & \multicolumn{2}{c}{ Xylanase } & \multicolumn{2}{c}{$\beta$-xylosidase } & $\alpha$-L-arabinofuranosidase \\
\cline { 2 - 7 } & U/g dry BSG & U/mg prot. & $\begin{array}{c}\text { mU/g dry } \\
\text { BSG }\end{array}$ & mU/mg prot. & $\begin{array}{c}\text { mU/g dry } \\
\text { BSG }\end{array}$ & mU/mg prot. \\
\hline 20 & $231.0 \pm 5.8$ & $115.1 \pm 3.9$ & $246.5 \pm 11.4$ & $124.5 \pm 9.6$ & $371.7 \pm 19.0$ & $192.9 \pm 19.0$ \\
25 & $370.2 \pm 10.7$ & $160.4 \pm 4.6$ & $225.1 \pm 5.7$ & $97.4 \pm 2.5$ & $403.4 \pm 21.8$ & $181.5 \pm 9.2$ \\
30 & $318.9 \pm 6.6$ & $140 \pm 1.9$ & $210.3 \pm 8.9$ & $92.5 \pm 8.9$ & $674.6 \pm 24.7$ & $296.5 \pm 11.5$ \\
35 & $\mathrm{ND}$ & $\mathrm{ND}$ & $\mathrm{ND}$ & $\mathrm{ND}$ & $\mathrm{ND}$ & $\mathrm{ND}$ \\
\hline
\end{tabular}

Cultivation was carried in $250 \mathrm{~mL}$ Erlenmeyer flasks containing $5 \mathrm{~g}$ of dried BSG with $50 \%(\mathrm{v} / \mathrm{w})$ initial moisture established with Vogel's salt solution for 7 days. Data are mean and standard deviation of triplicates. ND: not detected

\section{Analyses of the Fermented Material}

Table 3 presents data of chemical composition of the BSG before and after $P$. janczewskii growth. Such data are important because they represent an initial analysis of the product that will essentially define its nutritional value. After fungal growth, the composition changed mainly in relation to the hemicellulose fraction, i.e., the reduction in the hemicellulose fraction can be associated with the action of the xylanolytic enzymes produced by the fungus. The cellulose fraction was not changed, suggesting, as previously observed in liquid cultures (TERRASAN et al., 2010), the low or the absence of cellulolytic activity. Increase in the lignin content in relation to total dry matter may be directly related to the reduction of the hemicellulose. Furthermore, it was observed an increase in the protein content that is associated with the colonization and growth of the microbial biomass in the substrate. The decrease of TDN during fungal growth is not advantageous for application of the fermented substrate as a component of animal feed. The increase in mineral matter may be attributed to the salts present in the Vogel's solution added prior to the cultivation.

Amino acid composition was determined (Table 4) instead of analysis of total nitrogen because the last includes the non-protein nitrogen content such as that from nucleic acids that do not have nutritional value. Thus, this analysis can be considered a more realistic analysis of the protein content. Statistically different changes in amino acid 
composition were observed only for alanine, histidine, proline and lysine.

Table 3. Chemical composition of fermented and non-fermented brewer's spent grain.

\begin{tabular}{ccc}
\hline Analysis & $\begin{array}{c}\text { Control } \\
(\%)\end{array}$ & $\begin{array}{c}\text { Fermented } \\
\text { BSG } \\
(\%)\end{array}$ \\
\hline Dry matter & 96.44 & 95.89 \\
Ether extract & 2.79 & 3.23 \\
Mineral & 3.92 & 4.46 \\
matter & 17.53 & 19.95 \\
Total nitrogen & 72.07 & 72.27 \\
NFD & 39.27 & 42.69 \\
AFD & 22.32 & 23.01 \\
Cellulose & 32.81 & 29.59 \\
Hemicellulose & 16.94 & 19.68 \\
Lignin & 43.83 & 40.80 \\
TDN &
\end{tabular}

The results are expressed as percentage of dry matter. NFD: Neutral detergent fiber; AFD: A $c i d$ detergent fiber; TDN: total digestible nutrient (WEISS et al., 1992).

Table 4. Amino acid composition of fermented and non-fermented BSG.

\begin{tabular}{ccccc}
\hline & \multicolumn{2}{c}{ Control } & \multicolumn{2}{c}{ Fermented } \\
Amino acid & \multicolumn{3}{c}{ BSG } \\
\cline { 2 - 5 } & $\begin{array}{c}\text { g/100g } \\
\text { dry }\end{array}$ & $\begin{array}{c}\text { Total } \\
\text { BSG }\end{array}$ & $\begin{array}{c}\text { dry } \\
\text { drys }\end{array}$ & $\begin{array}{c}\text { BSG } \\
\text { Total } \\
\text { mass }\end{array}$ \\
\hline Aspartic Acid & 1.44 & 8.93 & 1.10 & 6.43 \\
Threonine & 0.73 & 4.57 & 0.80 & 4.72 \\
Serine & 0.66 & 4.13 & 0.70 & 4.09 \\
Glutamic & 2.59 & 16.10 & 2.91 & 17.09 \\
Acid & & & & \\
Proline* & 0.81 & 5.04 & 0.58 & 3.42 \\
Glycine & 0.93 & 5.78 & 1.03 & 6.06 \\
Alanine* & 1.00 & 6.21 & 1.22 & 7.17 \\
Cystein & 0.00 & 0.00 & 0.00 & 0.00 \\
Valine & 1.15 & 7.17 & 1.23 & 7.20 \\
Metionine & 0.25 & 1.55 & 0.29 & 1.69 \\
Isoleucine & 0.82 & 5.07 & 0.85 & 5.00 \\
Leucine & 1.52 & 9.43 & 1.70 & 9.97 \\
Tyrosine & 0.65 & 4.06 & 0.61 & 3.60 \\
Phenylalanine & 0.94 & 5.83 & 1.01 & 5.94 \\
Histidine* & 0.79 & 4.89 & 1.64 & 9.63 \\
Lysine* & 0.82 & 5.13 & 0.42 & 2.44 \\
Arginine & 0.98 & 6.12 & 0.95 & 5.56 \\
Total & 16.09 & - & 17.05 & - \\
\hline *Means statistically different by Mann-Whitney Test $(\mathrm{p} \leq 0,05)$.
\end{tabular}


Alanine and histidine concentrations were significantly higher in fermented BSG while proline and lysine concentrations significantly decreased after fungal growth. These results are important for amino acids balance in formulating a bio-product intended to animal nutrition, considering that histidine is an important amino acid to monogastrics and ruminants. However, the concentration of lysine, also an important amino acid for nutrition, decreased after cultivation. In this sense, the evaluation of other additional micronutrients in medium composition is required for balancing the final product. Ultimately, processing this material by with Penicillium janczewskii increased the overall amino acid content.

Mycotoxins analysis revealed the fungus did not produce mycotoxins during cultivation on BSG. In fact, reduction of deoxynivalenol and zearalenone found in non-fermented BSG (at lower concentrations than those established by Brazilian, UE and EUA legislations for feedstuffs or animal feed) was observed after fungal growth (Table 5).

Table 5. Mycotoxin analysis of the fermented and non-fermented BSG.

\begin{tabular}{|c|c|c|c|}
\hline \multicolumn{2}{|c|}{ Mycotoxin } & $\begin{array}{l}\text { Control } \\
(\mu \mathrm{g} / \mathrm{kg})\end{array}$ & $\begin{array}{c}\text { Fermented } \\
\mathrm{BSG} \\
(\mu \mathrm{g} / \mathrm{kg})\end{array}$ \\
\hline \multirow{4}{*}{ Aflatoxin } & B1 & $<0,1^{*}$ & $<0,1^{*}$ \\
\hline & B2 & $<0,1^{*}$ & $<0,1^{*}$ \\
\hline & G1 & $<0,1^{*}$ & $<0,1^{*}$ \\
\hline & G2 & $<0,1^{*}$ & $<0,1^{*}$ \\
\hline \multicolumn{2}{|c|}{ Ochratoxin A } & $<0,2^{*}$ & $<0,2^{*}$ \\
\hline \multicolumn{2}{|c|}{ Deoxynivalenol } & 95 & 71 \\
\hline \multicolumn{2}{|c|}{ Zearalenone } & 125 & 48 \\
\hline \multicolumn{2}{|l|}{ Patulin } & $<5^{*}$ & $<5^{*}$ \\
\hline
\end{tabular}

\section{CONCLUSIONS}

Brewer's spent grain can be considered a very suitable substrate for the production of xylanolytic enzymes by $P$. janczewskii in solid-state cultivation, especially in order to replace wheat bran, widely used in the production of food and feed, which cannot be considered as an inexpensive substrate anymore.

Cultivation of the fungus $P$. janczewskii on this substrate is an interesting alternative to improve the nutritional quality and add value to this byproduct of the brewing industry.

The fermented BSG might be used to compose the diet of animals as a supplement with higher protein content, which, moreover, contains xylanolytic enzymes that may improve its digestibility with no health risks, once mycotoxins are absent. In this sense, the conditions selected for the production of high levels of xylanase, $\beta$ xylosidase and $\alpha$-L-arabinofuranosidase by this fungal strain when cultured with this solid residue was $50 \%$ initial moisture provided by Vogel's salt solution and the cultivation carried out for seven days at $20-30{ }^{\circ} \mathrm{C}$.

\section{ACKNOWLEDGMENTS}

The authors gratefully acknowledge to São Paulo Research Foundation FAPESP/Brazil by the doctoral research fellowship (2007/08640-8) awarded to the first author.

RESUMO: Nas últimas décadas, há interesse crescente nas enzimas xilanolíticas devido à sua potencial utilização em muitos processos industriais. Este estudo descreve a produção de xilanase, $\beta$-xilosidase e $\alpha$-Larabinofuranosidase, três enzimas do complexo xilanolítico, por Penicillium janczewski utilizando bagaço de cevada como substrato para fermentação em estado sólido. As condições selecionadas para a produção de elevados níveis de xilanase, $\beta$ xilosidase e $\alpha$-L-arabinofuranosidase por esta linhagem fúngica foram $50 \%$ de umidade inicial, sendo esta fornecida por uma solução de sais de Vogel e cultivo por sete dias a $20-30{ }^{\circ} \mathrm{C}$. O bioproduto fermentado foi enriquecido com alguns aminoácidos e se apresentou livre de micotoxinas. O uso do bagaço de cerveja como substrato para o cultivo de fungos e produção de enzimas não só pode agregar valor a esses resíduos, mas também reduzir o custo de produção de enzimas xilanolíticas. 
PALAVRAS-CHAVE: Produção de enzimas. Enzimas xilanolíticas. Penicillium janczewskii. Fermentação em estado sólido. Bagaço de cevada.

\section{REFERENCES}

ALIYU, S.; BALA, M. Brewer's spent grain: a review of its potentials and applications. Afr. J. Biotechnol., Nairobi, v. 10, p. 324-331, 2011. doi: 10.5897/AJBx10.006

AOAC - Association of Official Analytical Chemists. Official Methods of Analysis. 12. ed. Washington. 1990, $1098 \mathrm{p}$.

BAILEY, M. J.; BIELY, P.; POUTANEN, K. Interlaboratory testing of methods for assay of xylanase activity. J. Biotechnol., Amsterdam, v. 23, p. 257-270, 1992. doi: 10.1016/0168-1656(92)90074-J

BAKRI, Y.; JACQUES, P.; THONART, P. Xylanase production by Penicillium canescens 10-10c in solid-state fermentation. Appl. Biochem. Biotechnol., Clifton, v. 108, p. 737-748, 2003. doi: 10.1007/978-1-4612-00574_61

BEG, Q. K.; KAPOOR, M.; MAHAJAN, L.; HOONDAL, G. S. Microbial xylanases and their industrial applications: a review. Appl. Microbiol. Biotechnol., Berlin, v. 56, p. 326-338, 2001. doi:

$10.1007 / \mathrm{s} 002530100704$

BIELY, P. Microbial xylanolytic systems. Trends Biotechnol., Amsterdan 3:286-290, 1985. doi: 10.1016/0167-7799(85)90004-6

BIELY, P. Xylanolytic enzymes. In: WHITAKER, J. R.; VORAGEN, A. G. J.; WONG, D. W. S. (Eds.) Handbook of Food Enzymology. New York: Marcel Dekker Inc., 2003, p. 879-916.

CHÁVEZ, R.; BULL, P.; EYZAGUIRRE, J. The xylanolytic enzyme system from the genus Penicillium. J. Biotechnol., Amsterdan, vol. 123, p. 413-433, 2006. doi: 10.1016/j.jbiotec.2005.12.036

DENSTALDI, V.; WESTERENG, B.; BINIYAM, H. G.; BALANCE, S.; KNUTSEN, H.; SVIHUS, B. Effects of structure and xylanase treatment of brewer's spent grain on performance and nutrient availability in broiler chickens. Brit. Poult. Sci., Edinburgh, v. 51, p. 419-426, 2010. doi: 10.1080/00071668.2010.495745

ENTWISLE, A. C.; WILLIAMS, A. C.; MANN, P. J.; RUSSELL, J.; SLACK, P. T.; GILBERT, J. Combined phenyl silane and immunoaffinity column clean-up with liquid chromatography for determination of ochratoxin A in roasted coffee: collaborative study. J. AOAC Int., Arlington, v. 84, p. 444-450, 2001.

EUROPEAN STANDARD EN 14123. Foodstuffs - Determination of aflatoxin B 1 and the sum of aflatoxin B 1 , $\mathrm{B}_{2}, \mathrm{G}_{1}$ and $\mathrm{G}_{2}$ in hazelnuts, peanuts, pistachios, figs, and paprika powder - High performance liquid chromatographic method with post-column derivatisation and immunoaffinity column cleanup: British Standards, 2007. 32p.

FOUNTOULAKIS, M.; LAHM, H-W. Hydrolysis and amino acid composition analysis of proteins. J. Chromatogr. A, New York, v. 826, p. 109-134, 1998. doi: 10.1016/S0021-9673(98)00721-3

GRAMINHA, E. B. N.; GONÇALVES, A. Z. L.; PIROTA, R. D. P. B.; BALSALOBRE, M. A. A.; SILVA, R.; GOMES, E. Enzyme production by solid-state fermentation: application to animal nutrition. Anim. Feed Sci.

Technol., Amsterdan v. 144, p. 1-22, 2008. doi: 10.1016/j.anifeedsci.2007.09.029 
KALOGERIS, E.; CHRISTAKOPOULOS, P; KEKOS, D.; MACRIS, B. J. Studies on the solid-state production of thermostable endoxylanases from Thermoascus aurantiacus: characterization of two isozymes. $\mathbf{J}$. Biotechnol., Amsterdan, v. 60, p. 155-163, 1998. doi: 10.1016/S0168-1656(97)00186-7

KERSTERS-HILDERSON, H.; CLAEYSSENS, M.; DOORSLAER, E. V.; SAMAN, E.; DE BRUYNE, C. K. $\beta$-D-xylosidase from Bacillus pumilus. Methods Enzymol., New York, v. 83, p. 631-639, 1982. doi: 10.1016/0076-6879(82)83062-0

KNOB, A.; TERRASAN, C. R. F.; CARMONA, E. C. $\beta$-xylosidases from filamentous fungi: an overview. World J. Microbiol. Biotechnol., Berlin, v. 26, p. 389-407, 2010. doi: 10.1007/s11274-009-0190-4

MACIEL, G. M.; VANDENBERGHE, L. P. S.; HAMINIUK, C. W. I.; FENDRICH, R. C.; BIANCA, E. D.; BRANDALIZE, T. Q. S.; PANDEY, A.; SOCCOL, C. R. Xylanase production by Aspergillus niger LPB 326 in solid-state fermentation using statistical experimental design. Food Technol. Biotechnol., Zagreb, v. 46, p. 183-189, 2008.

MAMMA, D.; KOURTOGLOU, E.; CHRISTAKOPOULOS, P. Fungal multienzyme production on industrial by-products of the citrus-processing industry. Bioresour. Technol., New York, v. 99, p. 2373-2383, 2007. doi: 10.1016/j.biortech.2007.05.018

MANDALARI, G.; BISIGNANO, G.; LO CURTO, R. B.; WALDRON, K. W.; FAULDS, C. B. Production of feruloyl esterases and xylanases by Talaromyces stipitatus and Humicola grisea var. thermoidea on industrial food processing by-products. Bioresour. Technol., New York, v. 99, p. 5130-5133, 2008. doi: 10.1016/j.biortech.2007.09.022

MILLER, G. H. Use of dinitrosalicylic acid reagent for determination of reducing sugar. Anal. Chem., Washington, v. 31, p. 426-429, 1959. doi: 10.1021/ac60147a030

MUSSATTO, S. I.; DRAGONE, G.; ROBERTO, I. C. Brewer's spent grain: generation, characteristics and potential application. J. Cereal Sci., London, v. 43, p. 1-14, 2006. doi: 10.1016/j.jcs.2005.06.001

MUSSATTO, S. I.; ROBERTO, I. C. Chemical characterization and liberation of pentose sugars from brewer's spent grain. J. Chem. Technol. Biotechnol., Chichester Sussex, v. 81, p. 268-274, 2006. doi: $10.1002 /$ jctb. 1374

NARANG, S.; SAHAI, V.; BISARIA, B. V. Optimization of xylanase production by Melanocarpus albomyces IS68 in solid-state fermentation using response surface methodology. J. Biosci. Bioeng., Osaka, v. 91, p. 425427, 2001. doi: 10.1016/S1389-1723(01)80164-X

NASCIMENTO, R.P.; COELHO, R. R. R.; MARQUES, S.; ALVES, L.; GÍRIO, F. M.; BON, E. P. S. AMARAL-COLLAÇO, M. T. Production and partial characterization of xylanase from Streptomyces sp strain AMT-3 isolated from Brazilian Cerrado soil. Enzyme Microb. Technol., New York, v. 31, p. 549-555, 2002. doi: 10.1016/S0141-0229(02)00150-3

PANAGIOTOU, G.; GRANOUILLET, P.; OLSSON, L. Production and partial characterization of arabinoxylan-degrading enzymes by Penicillium brasilianum under solid-state fermentation. Appl. Microbiol Biotechnol., Berlin, v. 72, p. 1117-1124, 2006. doi: 10.1007/s00253-006-0394-6

PANAGIOTOU, G.; OLAVARRIA, R.; OLSSON, L. Penicillium brasilianum as an enzyme factory, the essential role of feruloyl esterases for the hydrolysis of the plant cell wall. J. Biotechnol., Amsterdan, v. 130, p. 219-228, 2007. doi: 10.1016/j.jbiotec.2007.04.011

POLIZELI, M. L. T.; RIZZATTI, A. C. S.; MONTI, R.; TERENZI, H. F.; JORGE, J. A.; AMORIM, D. S. Xylanases from fungi: properties and industrial applications. Appl. Microbiol. Biotechnol., Berlin, v. 67, p. 577-591, 2005. doi: 10.1007/s00253-005-1904-7 
SEDMAK, J. J.; GROSSBERG, S. E. A rapid, sensitive and versatile assay for protein using Coomassie Brilliant Blue G250. Anal. Biochem., New York, v. 78, p. 544-552, 1977. doi: 10.1016/0003-2697(77)90428-6

SINGHANIA, R. R.; PATEL, A.K.; SOCCOL, C.R.; PANDEY, A. Recent advances in solid-state fermentation. Biochem. Eng. J., Amsterdan, v. 44, p. 13-18, 2009. doi:10.1016/j.bej.2008.10.019

SOCCOL, C. R.; VANDENBERGH, L. P. S. Overview of applied solid-state fermentation in Brazil. Biochem. Eng. J., Amsterdan, v. 13, p. 205-218, 2003. doi:10.1016/S1369-703X(02)00133-X

TERRASAN, C. R. F.; TEMER, B.; DUARTE, M. C. T.; CARMONA, E. C. Production of xylanolytic enzymes by Penicillium janczewskii. Bioresour. Technol., New York, v. 101, p. 4139-4143, 2010. doi: 10.1016/j.biortech.2010.01.011

VAN SOEST, P. J. Nutritional Ecology of the Ruminant. 2. ed. New York: Cornell University, 1994. 476 p.

VOGEL, H. J. A convenient growth medium for Neurospora (Medium N). Microbial Genet. Bull., v. 13, p. 42-43, 1956.

WEISS, W. P.; CONRAD, H. R.; ST. PIERRE, N. R. A theoretically based model for predicting total digestible nutrient values of forages and concentrates. Anim. Feed Sci. Technol., Amsterdan, v. 39, p. 95-110, 1992. doi: $10.1016 / 0377-8401(92) 90034-4$

XIROS, C.; TOPAKAS, E.; KATAPODIS, P.; CHRISTAKOPOULOS, P. Evaluation of Fusarium oxysporum as an enzyme factory for the hydrolysis of brewer's spent grain with improved biodegradability for ethanol production. Ind. Crops Prod., Amsterdan, v. 28, p. 213-224, 2008a. doi: 10.1016/J.INDCROP.2008.02.004

XIROS, C.; TOPAKAS, E.; KATAPODIS, P.; CHRISTAKOPOULOS, P. Hydrolysis and fermentation of brewer's spent grain by Neurospora crassa. Bioresour. Technol., New York, v. 99, p. 5427-5435, 2008b. doi: 10.1016/j.biortech.2007.11.010

YANG, S. Q.; YAN, Q. J.; JIANG, Z. Q.; LI, L. T.; TIAN, H. M.; WANG, Y. Z. High-level of xylanase production by the thermophilic Paecilomyces themophila J18 on wheat straw in solid-state fermentation.

Bioresour. Technol., New York, v. 97, p. 1794-1800, 2006. doi: 10.1016/j.biortech.2005.09.007 